\title{
TEKNOLOGI BUDIDAYA BAWANG MERAH ASAL BIJI (Shallot Cultivation Technology from True Shallot Seed)
}

\author{
Atman \\ Balai Pengkajian Teknologi Pertanian Sumatera Barat \\ Jl. Raya Padang Solok Km 40, Sukarami, Gunung Talang Solok, \\ Sumatra Barat, Indonesia-27365 \\ email: atmanroja@yahoo.com
}

\begin{abstract}
Abstrak
Bawang merah adalah salah satu komoditas bahan makan penting di Indonesia dengan ratarata konsumsi per kapita sebesar 49,3 g per minggu. Provinsi Jawa Tengah, Jawa Timur, Nusa Tenggara Barat, Jawa Barat, Sulawesi Selatan, dan Sumatera Barat merupakan sentra produksi bawang merah. Sebagian besar budidaya bawang merah masih menggunakan umbi sebagai sumber benih dengan biaya pembelian yang sangat tinggi (Rp.45 juta/ha). Penggunaan sumber benih asal biji sangat berprospek dikembangkan di Indonesia karena dapat mengurangi biaya pembelian benih sampai 66,7\% dan mengurangi penggunaan hasil panen untuk sumber benih berikutnya (berkisar 10-15\% dari hasil). Permasalahannya, informasi tentang teknologi budidaya bawang merah asal biji masih sedikit sehingga diperlukan penelitian-penelitian untuk mendapatkan komponen teknologi bawang merah spesifik lokasi. Informasi yang saat ini tersedia, antara lain: (1) Proses perbanyakan benih bawang merah dianjurkan di dataran tinggi (1.000-1.500 $\mathrm{m} \mathrm{dpl);} \mathrm{(2)} \mathrm{Tersedia} \mathrm{beberapa}$ varietas, seperti; Bima, Pikatan, Tuk Tuk, Tajuk, BM 8705, Sanren, Manjung, Trisula, dan Pancasona, namun perlu diuji daya adaptasinya pada lokasi spesifik; (3) Penanaman di dataran tinggi sebaiknya lebih rapat dibandingkan di dataran rendah; dan (4) Pupuk organik dan anorganik sangat diperlukan, namun informasi tentang dosis, cara, dan waktu pemberiannya berdasarkan spesifik lokasi sedikit.
\end{abstract}

Kata kunci: bawang merah, biji, budidaya, kerapatan tanaman, pupuk, benih.

\begin{abstract}
Shallots are one of the important food commodities in Indonesia with an average consumption per capita of 49.3 grams per week. The provinces of Central Java, East Java, West Nusa Tenggara, West Java, South Sulawesi and West Sumatra are centers of shallots production. Most shallot cultivation still uses tubers as a source of seeds with very high purchase costs (Rp.45 million / ha). The use of seed sources from true shallot seeds is very prospective to be developed in Indonesia because it can reduce the cost of purchasing seeds by up to $66.7 \%$ and reduce the use of yields for subsequent seed sources (ranging from 10-15\% of yield). The problem is that information about true shallot seed cultivation technology is still small, so research is needed to obtain a specific location component of shallot technology. Information currently available includes: (1) The process of propagation of shallot seeds is recommended in the highlands (1,000-1,500 $\mathrm{m}$ asl); (2) Several varieties are available, such as; Bima, Pikatan, Tuk Tuk, Tajuk, BM 8705, Sanren, Manjung, Trisula and Pancasona, but their adaptability must be tested at specific locations; (3) Planting in the highlands should be more dense than in the lowlands; and (4) Organic and inorganic fertilizers are needed, but information on dosage, method, and time of application based on location-specific is minimal.
\end{abstract}

Keywords: shallots, cultivation, plant density, fertilizer, seeds. 


\section{PENDAHULUAN}

Bawang merah (Allium ascalonicum L.) merupakan salah satu komoditas bahan makan penting di Indonesia. Pada tahun 2017, rata-rata konsumsi per kapita sebesar 49,3 g per minggu. Penanaman komoditas ini menyebar di seluruh provinsi, kecuali Provinsi Kepulauan Riau. Daerah sentra produksi bawang merah terdapat di Provinsi Jawa Tengah, Jawa Timur, Nusa Tenggara Barat, Jawa Barat, Sulawesi Selatan, dan Sumatera Barat. Areal luas panen bawang merah selalu mengalami peningkatan dari tahun ke tahun yaitu 120.704 ha, 122.126 ha, 149.635 ha, dan 158,172 ha, namun sebaliknya produktivitasnya mengalami penurunan dari tahun ke tahun yaitu 10,22 t/ha, 10,06 t/ha, 9,67 t/ha, dan 9,29 t/ha berturut-turut pada tahun 2014, 2015, 2016, dan 2017 (BPS 2018).

Permasalahannya, peningkatan areal penanaman bawang merah mengakibatkan kebutuhan benih yang berasal dari umbi juga meningkat. Menurut Pangestuti dan Sulistyaningsing (2011), kendala penyediaan benih bermutu asal umbi pada saat tanam, antara lain: (1) Memerlukan biaya penyediaan benih asal umbi yang besar; (2) Membutuhkan benih asal umbi yang sangat besar; (3) Membutuhkan gudang penyimpanan karena jumlah yang banyak dan adanya masa dormansi; (4) Umur penggunaan benih asal umbi singkat, mutu benih akan menurun setelah 4 bulan dan akan rusak setelah 6 bulan; (5) Distribusi benih asal umbi antar petani/daerah membutuhkan biaya besar; dan (6) Tingginya variasi mutu benih asal umbi dan rendahnya produktivitas. Dalam hal penyediaan umbi benih, jika diasumsikan rata-rata penggunaan benih asal umbi sebanyak 1,5 t/ha dengan harga Rp.30.000/kg maka dibutuhkan benih asal umbi sebanyak 181.056 ton, 183.189 ton, 224.453 ton, dan 237.258 ton dengan biaya pembelian sebanyak Rp.5,4 triliun, Rp.5,5 triliun, Rp.6.7 triliun, dan Rp.7,1 triliun berturutturut pada tahun 2014, 2015, 2016, dan 2017. Selain terkurasnya dana akibat pembelian benih asal umbi yang sangat banyak (Rp.45 juta/ha), menjadikan hasil panen untuk memenuhi kebutuhan benih asal umbi pada penanaman musim berikutnya yang cukup besar (berkisar 10$15 \%$ dari hasil panen) merupakan salah satu ancaman untuk keberhasilan program swasembada bawang merah, utamanya dalam memasok bawang merah untuk konsumsi masyarakat Indonesia.

Berdasarkan hal diatas, Kementerian Pertanian sejak tahun 2014 telah mulai mengembangkan teknologi benih umbi mini yang berasal dari biji (TSS=True Shallot Seed). Penggunaan benih umbi mini ini mampu mengurangi kebutuhan benih hampir separonya (ratarata $750 \mathrm{~kg}$ umbi mini/ha). Selanjutnya, sejak tahun 2018 juga dikembangkan budidaya bawang merah untuk konsumsi dengan menggunakan benih berasal dari biji. Penggunaan benih bawang merah yang berasal dari biji ini akan dapat menghemat biaya pembelian benih sampai $66,7 \%$, dengan asumsi kebutuhan benih sebanyak $5 \mathrm{~kg} / \mathrm{ha}$ dengan harga benih sebesar Rp.3 juta/kg (Rp.15 juta/ha). Namun demikian, budidaya bawang merah asal biji ini belum berkembang pesat di tingkat pengguna (petani) karena masih sedikitnya informasi tentang teknologi budidayanya. Untuk itu, tulisan ini menampilkan informasi tentang teknologi budidaya bawang merah asal biji sehingga stakeholder terkait dapat memanfaatkannya.

\section{KESESUAIAN LAHAN}

Untuk mendapatkan produktivitas bawang merah asal biji yang tinggi, kelas kesesuaian lahan dapat dipedomani karena berkaitan dengan tambahan masukan (input) usahatani. Ritung, Nugroho, Mulyani, dan Suryani (2011) membagi 
kesesuaian lahan untuk komoditas bawang merah atas empat kelas, yaitu: sangat sesuai (S1), cukup sesuai (S2), sesuai marginal (S3), dan tidak sesuai (N), seperti disajikan pada Tabel 1. Kelas S1 memiliki faktor pembatas yang minor dan tidak mereduksi produktivitas lahan secara nyata. Kelas S2 memiliki faktor pembatas yang memerlukan tambahan masukan, namun masih dapat diatasi petani. Kelas S3 memiliki faktor pembatas yang memerlukan tambahan masukan lebih banyak sehingga memerlukan modal besar dan bantuan pemerintah atau swasta. Kelas $\mathrm{N}$ memiliki faktor pembatas sangat berat dan sulit diatasi.

Tabel 1. Kelas kesesuaian lahan untuk komoditas bawang merah.

\begin{tabular}{|c|c|c|c|c|}
\hline \multirow{2}{*}{$\begin{array}{l}\text { Persyaratan Penggunaan/ } \\
\text { Karakteristik Lahan }\end{array}$} & \multicolumn{4}{|c|}{ Kelas Kesesuaian Lahan } \\
\hline & S1 & S2 & S3 & $\mathbf{N}$ \\
\hline $\begin{array}{l}\text { Temperatur } \\
\text { Temperatur rata-rata }\left({ }^{\circ} \mathrm{C}\right)\end{array}$ & $20-25$ & $\begin{array}{l}25-30 \\
18-20\end{array}$ & $\begin{array}{l}30-35 \\
15-18\end{array}$ & $\begin{array}{l}>35 \\
<15\end{array}$ \\
\hline $\begin{array}{l}\text { Ketersediaan air } \\
\text { Curah hujan/tahun (mm) }\end{array}$ & $350-600$ & $\begin{array}{l}600-800 \\
300-350\end{array}$ & $\begin{array}{c}800-1.600 \\
230-500\end{array}$ & $\begin{array}{l}>1.600 \\
<250\end{array}$ \\
\hline $\begin{array}{l}\text { Ketersediaan oksigen } \\
\text { Drainase }\end{array}$ & $\begin{array}{l}\text { baik, agak } \\
\text { terhambat }\end{array}$ & $\begin{array}{l}\text { agak cepat, } \\
\text { sedang }\end{array}$ & terhambat & $\begin{array}{c}\text { sangat terhambat, } \\
\text { cepat }\end{array}$ \\
\hline $\begin{array}{l}\text { Media perakaran } \\
\text { Tekstur } \\
\text { Bahan kasar }(\%) \\
\text { Kedalaman tanah }(\mathrm{cm})\end{array}$ & $\begin{array}{l}\text { Agak halus, } \\
\text { sedang } \\
>15 \\
>50\end{array}$ & $\begin{array}{l}\text { Halus } \\
15-35 \\
30-50 \\
\end{array}$ & $\begin{array}{c}\text { Agak kasar, } \\
\text { sangat halus } \\
35-55 \\
20-30 \\
\end{array}$ & $\begin{array}{l}\text { Kasar } \\
>55 \\
<20 \\
\end{array}$ \\
\hline $\begin{array}{l}\text { Gambut } \\
\text { Ketebalan }(\mathrm{cm}) \\
\text { Kematangan } \\
\end{array}$ & $\begin{array}{c}<50 \\
\text { saprik }\end{array}$ & $\begin{array}{c}50-100 \\
\text { Saprik, hemik }\end{array}$ & $\begin{array}{l}100-150 \\
\text { hemik }\end{array}$ & $\begin{array}{l}>150 \\
\text { hemik }\end{array}$ \\
\hline $\begin{array}{l}\text { Retensi hara } \\
\text { KTK tanah }(\mathrm{cmol}) \\
\text { Kejenuhan basa }(\%) \\
\text { pH } \mathrm{H}_{2} \mathrm{O} \\
\text { C-organik }\end{array}$ & $\begin{array}{c}>16 \\
>35 \\
6,0-7,8 \\
>2\end{array}$ & $\begin{array}{c}5-16 \\
20-35 \\
5,8-6,0 \\
7,8-8,0 \\
0,8-2,0\end{array}$ & $\begin{array}{l}<5 \\
<20 \\
<5,8 \\
>8,0 \\
<0,8\end{array}$ & \\
\hline $\begin{array}{l}\text { Hara tersedia } \\
\text { N-total }(\%) \\
\mathrm{P}_{2} \mathrm{O}_{5}(\mathrm{mg} / 100 \mathrm{~g}) \\
\mathrm{K}_{2} \mathrm{O}(\mathrm{mg} / 100 \mathrm{~g})\end{array}$ & $\begin{array}{l}\text { Sedang } \\
\text { Tinggi } \\
\text { sedang }\end{array}$ & $\begin{array}{l}\text { Rendah } \\
\text { Sedang } \\
\text { rendah }\end{array}$ & $\begin{array}{l}\text { Sangat rendah } \\
\text { Rendah-sgt } \\
\text { rendah } \\
\text { Sangat rendah }\end{array}$ & \\
\hline $\begin{array}{l}\text { Toksisitas } \\
\text { Salinitas }(\mathrm{dS} / \mathrm{m}) \\
\end{array}$ & $<2$ & $2-3$ & $3-5$ & $>5$ \\
\hline $\begin{array}{l}\text { Sodisitas } \\
\text { Alkalinitas/ESP }(\%)\end{array}$ & $<20$ & $20-35$ & $35-50$ & $>50$ \\
\hline $\begin{array}{l}\text { Bahaya sulfidik } \\
\text { Kedalaman sulfidik }(\mathrm{cm})\end{array}$ & $>75$ & $50-75$ & $30-50$ & $<30$ \\
\hline $\begin{array}{l}\text { Bahaya erosi } \\
\text { Lereng }(\%) \\
\text { Bahaya erosi }\end{array}$ & $<3$ & $\begin{array}{c}3-8 \\
\text { Sangat ringan }\end{array}$ & $\begin{array}{c}\text { 8-15 } \\
\text { Ringan-sedang }\end{array}$ & $\begin{array}{c}> \\
\text { Berat-sgt berat }\end{array}$ \\
\hline $\begin{array}{l}\text { Bahaya banjir/genangan masa } \\
\text { tanam } \\
\text { Tinggi }(\mathrm{cm}) \\
\text { Lama (hari) }\end{array}$ & & & & $\begin{array}{l}25 \\
<7\end{array}$ \\
\hline $\begin{array}{l}\text { Penyiapan lahan (lp) } \\
\text { Batuan dipermukaan }(\%) \\
\text { Singkapan batuan }(\%)\end{array}$ & $\begin{array}{l}<5 \\
<5\end{array}$ & $\begin{array}{l}5-15 \\
5-15\end{array}$ & $\begin{array}{l}15-40 \\
15-25\end{array}$ & $\begin{array}{l}>40 \\
>25\end{array}$ \\
\hline
\end{tabular}

Sumber: Ritung, et. al. (2011) 


\section{TEKNOLOGI BUDIDAYA}

\section{- Perbenihan}

Usaha perbanyakan benih bawang merah dalam bentuk biji merupakan salah satu kegiatan yang mempunyai prospek untuk dikembangkan pada masa mendatang. Hal yang perlu mendapat perhatian dalam perbanyakan benih dalam bentuk biji ini antara lain: (1) lokasi sebaiknya pada daerah yang bersuhu rendah atau ketinggian tempat 1.000-1.500 m dpl (di atas permukaan laut); (2) sebaiknya melalui penyerbukan silang; dan (3) hindari tanaman dari kondisi curah hujan sangat tinggi dan angin kencang (Sembiring, Rosliani, Simatupang, dan Prahardini, 2018). Namun, hasil penelitian Rosliani, Palupi, dan Hilman (2013) menyatakan bahwa ada peluang untuk memperbaiki tingkat pembungaan yang lebih tinggi di dataran rendah, sedangkan tantangannya ialah peningkatan pembentukan kapsul/buah dan biji TSS (benih botani bawang merah). Selanjutnya dinyatakan bahwa pemberian BAP (benzilaminopurin) dapat meningkatkan pembungaan dan viabilitas serbuk sari bawang merah, tetapi tidak meningkatkan produksi dan mutu benih TSS di dataran rendah Subang. Aplikasi BAP konsentrasi 50 ppm yang diaplikasikan pada umur 1, 3, dan 5 MST (minggu setelah tanam) cukup memadai untuk meningkatkan pembungaan bawang merah di dataran rendah Subang (Tabel 2). Sementara boron tidak memperbaiki tingkat pembungaan maupun produksi dan mutu benih TSS. Boron $4 \mathrm{~kg} / \mathrm{ha}$ hanya dapat memperbaiki viabilitas serbuk sari bawang merah.

Tabel 2. Pengaruh perlakuan BAP dan Boron terhadap viabilitas dan jumlah serbuk sari serta jumlah, persentase, dan bobot TSS (benih botani bawang merah).

\begin{tabular}{|c|c|c|c|c|c|}
\hline Perlakuan & $\begin{array}{c}\text { Viabilitas } \\
\text { Serbuk Sari }\end{array}$ & $\begin{array}{c}\text { Jumlah } \\
\text { Serbuk Sari } \\
\text { per anter }\end{array}$ & $\begin{array}{c}\text { Jumlah TSS } \\
\text { per umbel }\end{array}$ & $\begin{array}{l}\text { Persentase } \\
\text { TSS Bernas }\end{array}$ & $\begin{array}{l}\text { Bobot TSS } \\
\text { per umbel }\end{array}$ \\
\hline \multicolumn{6}{|c|}{ Konsentrasi BAP (ppm) } \\
\hline 0 & $1,57 \mathrm{~b}$ & $813,1 \mathrm{a}$ & 69,7 abc & $54,15 \quad b$ & $0,337 \mathrm{a}$ \\
\hline 50 & $1,77 \mathrm{~b}$ & $830,1 \mathrm{a}$ & $101,1 \mathrm{a}$ & $81,75 \mathrm{a}$ & $0,410 \mathrm{a}$ \\
\hline 100 & $2,00 \mathrm{ab}$ & $829,4 \mathrm{a}$ & $69,6 \mathrm{abc}$ & $79,47 \mathrm{a}$ & $0,300 \mathrm{a}$ \\
\hline 150 & $1,90 \mathrm{ab}$ & $824,8 \mathrm{a}$ & $52,2 \quad \mathrm{c}$ & $52,04 \quad b$ & $0,267 \mathrm{a}$ \\
\hline 200 & $2,33 \mathrm{a}$ & $788,3 \mathrm{a}$ & $85,7 \mathrm{ab}$ & $77,58 \mathrm{a}$ & $0,299 \mathrm{a}$ \\
\hline Rata-rata & 1,91 & 817,1 & $\mathbf{7 5 , 5}$ & 68,99 & $\mathbf{0 , 3 2 3}$ \\
\hline \multicolumn{6}{|c|}{ Dosis Boron (kg/ha) } \\
\hline 0 & $1,40 \quad \mathrm{c}$ & $779,2 \mathrm{a}$ & $79,9 \mathrm{a}$ & $68,12 \mathrm{a}$ & $0,331 \mathrm{a}$ \\
\hline 1 & 1,77 bc & $799,1 \mathrm{a}$ & $79,9 \mathrm{a}$ & $78,28 \mathrm{a}$ & $0,311 \mathrm{a}$ \\
\hline 2 & $2,17 \mathrm{ab}$ & $832,7 \mathrm{a}$ & $61,1 \mathrm{a}$ & $61,27 \mathrm{a}$ & $0,323 \mathrm{a}$ \\
\hline 3 & 1,80 bc & $829,9 \mathrm{a}$ & $77,6 \mathrm{a}$ & $66,85 \mathrm{a}$ & $0,299 \mathrm{a}$ \\
\hline 4 & $2,43 \mathrm{a}$ & $852,0 \mathrm{a}$ & $78,7 \mathrm{a}$ & $70,47 \mathrm{a}$ & $0,340 \mathrm{a}$ \\
\hline Rata-rata & 1,91 & 817,1 & 75,5 & 68,99 & 0,323 \\
\hline $\begin{array}{l}\text { BAP x } \\
\text { Boron }\end{array}$ & tn & tn & $\operatorname{tn}$ & tn & tn \\
\hline KK (\%) & 14,9 & 15,3 & 21,1 & 29,9 & 8,3 \\
\hline
\end{tabular}

tn=tidaknyata: Sumber: Rosliani, et. al. (2013)

Ditinjau dari sisi finansial, penelitian Sembiring, et. al. (2018) mendapatkan bahwa usaha perbanyakan biji bawang merah di dataran tinggi memberikan keuntungan sangat besar, yaitu: untuk Sumatera Utara dan Jawa 
Timur dengan nilai keuntungan sebesar Rp.602,7 juta/ha dan Rp.356,3 juta/ha serta nilai R/C berturut-turut 3,44 dan 2,63. Sedangkan di Jawa Tengah mengalami kerugian sebesar Rp.184,3 juta/ha dengan nilai $\mathrm{R} / \mathrm{C}$ 0,41 (Tabel 3). Kerugian ini disebabkan karena tingginya biaya sarana produksi, iklim yang tidak mendukung (curah hujan sangat tinggi, angin kencang), dan tingginya serangan penyakit.

Sementara itu, Nurjanani dan Djufry (2018) menguji kemampuan beberapa varietas dalam menghasilkan biji botani bawang merah (TSS) di Kabupaten Jeneponto (1.200 $\mathrm{m} \quad \mathrm{dpl})$ dengan menggunakan empat jenis varietas, yaitu: Trisula, Pancasona, Maja Cipanas, dan Mentes. Didapatkan bahwa varietas yang menghasilkan biji terbanyak adalah Trisula (4,90 g/rumpun) dan Pancasona (4,18 g/rumpun), dengan persentase tanaman berbunga masing-masing $93 \%$ dan $90 \%$. Berbeda dengan varietas Maja Cipanas dan Mentes yang menghasilkan biji masingmasing 1,85 g/rumpun dan 1,49 g/rumpun, sedangkan persentase tanaman yang berbunga pada varietas Maja Cipanas hanya $60 \%$ dan varietas Mentes $30 \%$ (Tabel 4). Kedua varietas ini (Trisula dan Pancasona) dapat direkomendasikan sebagai penghasil benih bawang merah dalam bentuk biji di dataran tinggi kering Sulawesi Selatan karena memiliki nilai $\mathrm{R} / \mathrm{C}$ ratio sebesar 1,3 yang berarti layak diusahakan.

Tabel 3. Analisis usahatani perbanyakan benih bawang merah dalam bentuk biji di Sumatera Utara, Jawa Timur, dan Jawa Tengah.

\begin{tabular}{|c|c|c|c|c|}
\hline \multirow{2}{*}{\multicolumn{2}{|c|}{ Uraian }} & \multicolumn{3}{|c|}{ Total Biaya/Penerimaan (Rp.) } \\
\hline & & \multirow{2}{*}{$\begin{array}{c}\text { Sumatera Utara } \\
120.729 .000 \\
\end{array}$} & \multirow{2}{*}{\begin{tabular}{|c|} 
Jawa Timur \\
74.208 .500
\end{tabular}} & \multirow{2}{*}{$\begin{array}{r}\text { Jawa Tengah } \\
106.675 .000\end{array}$} \\
\hline A & Material & & & \\
\hline & Benih & 36.000 .000 & 25.000 .000 & 37.500 .000 \\
\hline & Pupuk & 38.595 .000 & 30.650 .000 & 48.075 .000 \\
\hline & Pestisida & 14.710 .000 & 10.085 .000 & 10.600 .000 \\
\hline & Biaya lain-lain & 26.544 .000 & - & 4.500 .000 \\
\hline & Bahan bakar pengairan & 3.880 .000 & - & - \\
\hline & Bahan bakar penyemprotan & - & 223.500 & - \\
\hline & Vernalisasi & 1.000 .000 & 1.500 .000 & 1.000 .000 \\
\hline & Lebah madu & - & 3.000 .000 & 5.000 .000 \\
\hline & Tegetes & - & 3.750 .000 & - \\
\hline $\mathbf{B}$ & Tenaga Kerja & 68.400.000 & 75.000 .000 & 141.300.000 \\
\hline \multirow[t]{7}{*}{$\mathbf{C}$} & Lain-lain & & & \\
\hline & Depresiasi & - & - & - \\
\hline & Naungan $3 x$ pakai & 30.050 .000 & 36.387 .000 & 19.355 .000 \\
\hline & Mulsa & 3.000 .000 & 6.250 .000 & 6.000 .000 \\
\hline & Sewa lahan per musim & 5.000 .000 & 10.000 .000 & 15.000 .000 \\
\hline & Biaya tak terduga & 9.456 .450 & 7.460 .425 & 12.398 .750 \\
\hline & Bunga Bank atas modal & 10.648 .595 & 9.418 .767 & 13.532 .794 \\
\hline \multicolumn{2}{|c|}{ Total Biaya Produksi } & 247.284 .045 & 218.724.692 & 314.261.544 \\
\hline \multirow[t]{4}{*}{$\mathbf{D}$} & Penerimaan & & & \\
\hline & Hasil biji botani & 640.000 .000 & 230.000 .000 & 70.000 .000 \\
\hline & Hasil sampingan (umbi) & 200.000 .000 & 345.000 .000 & 60.000 .000 \\
\hline & Hasil sampingan (umbi) & 10.000 .000 & - & - \\
\hline \multicolumn{2}{|c|}{ Total Penerimaan } & 850.000 .000 & 575.000 .000 & 130.000 .000 \\
\hline \multirow{2}{*}{\multicolumn{2}{|c|}{$\begin{array}{l}\text { Keuntungan/Kerugian } \\
\text { R/C rasio }\end{array}$}} & 602.715 .955 & 356.275.308 & -184.261 .544 \\
\hline & & 3,44 & 2,63 & $\mathbf{0 , 4 1}$ \\
\hline
\end{tabular}

Sumber: Sembiring, et. al. (2018) 
Tabel 4. Pengaruh varietas pada proses pembijian bawang merah.

\begin{tabular}{|l|c|c|c|c|}
\hline \multicolumn{1}{|c|}{ Varietas } & $\begin{array}{c}\text { Kemampuan } \\
\text { Berbunga (\%) }\end{array}$ & $\begin{array}{c}\text { Jumlah Kapsul } \\
\text { per umbel }\end{array}$ & $\begin{array}{c}\text { Bobot Biji per } \\
\text { rumpun (g) }\end{array}$ & $\begin{array}{c}\text { Jumlah Biji } \\
\text { per rumpun }\end{array}$ \\
\hline Trisula & 93 & $64,77 \mathrm{~b}$ & $4,90 \mathrm{a}$ & $1.509 .00 \mathrm{a}$ \\
\hline Pancasona & 90 & $116,12 \mathrm{a}$ & $4,18 \mathrm{a}$ & $1.099,33 \mathrm{ab}$ \\
\hline Mentes & 30 & $58,89 \mathrm{~b}$ & $1,49 \mathrm{~b}$ & $727,33 \mathrm{~b}$ \\
\hline Maja Cipanas & 60 & $65,59 \mathrm{~b}$ & $1,85 \mathrm{~b}$ & $526,67 \mathrm{~b}$ \\
\hline KK (\%) & - & 11,88 & 18,35 & 16,26 \\
\hline
\end{tabular}

Angka-angka yang diikuti huruf yang sama pada kolom yang sama menunjukkan tidak berbeda nyata pada uji BNJ taraf 5\%.

Sumber: Nurjanani dan Djufry (2018)

\section{- Varietas Unggul}

Penelitian tentang tampilan beberapa varietas bawang merah asal biji telah dilakukan oleh Wati dan Sobir (2018) pada dataran tinggi Cianjur Jawa Barat (1.000 m dpl) dengan jenis tanah Andisol. Diuji sebanyak tujuh varietas, yaitu: Bima Brebes, Tuk-Tuk, Pikatan, Tajuk, BM 8705, Sanren, dan Manjung yang dibandingkan dengan varietas Bima Brebes asal umbi. Didapatkan bahwa nilai bobot basah per rumpun dan bobot kering per rumpun varietas Bima, Sanren, Manjung, dan BM 8705 (benih dari biji) tidak berbeda nyata dengan varietas pembanding (Bima, benih dari umbi). Artinya, benih yang berasal dari biji maupun yang berasal dari umbi memberikan hasil bobot umbi yang sama (Tabel 5). Perbedaan terlihat pada jumlah siung per rumpun, dimana varietas yang berasal dari umbi memberikan jumlah siung lebih banyak dibanding benih yang berasal dari biji (4-8 kali) sehingga untuk meningkatkan produktivitas bawang merah diperlukan peningkatan jumlah benih asal biji pada setiap rumpun tanaman bawang merah. Hasil penelitian Sumarni, Sopha, dan Gaswanto (2012) yang dilakukan di dataran rendah Cirebon mendapatkan bahwa perlakuan varietas tanaman bawang merah asal biji (Maja, Bima, dan Tuk-Tuk) tidak berpengaruh terhadap pertumbuhan dan hasil umbi bawang merah. Hasil penelitian yang berbeda didapatkan oleh (Saidah et al. 2019) di Kabupaten Sigi Sulawesi Tengah. Ternyata varietas Lokananta dan Sanren memiliki respon yang berbeda terhadap pertumbuhan dan hasil umbi bawang merah.

Tabel 5. Tampilan komponen hasil beberapa varietas bawang merah.

\begin{tabular}{|l|c|c|c|}
\hline \multicolumn{1}{|c|}{ Varietas } & $\begin{array}{c}\text { Jumlah Siung per } \\
\text { rumpun }\end{array}$ & $\begin{array}{c}\text { Bobot Basah per } \\
\text { rumpun (g) }\end{array}$ & $\begin{array}{c}\text { Bobot Kering per } \\
\text { rumpun (g) }\end{array}$ \\
\hline Bima (umbi) & $8,00 \mathrm{a}$ & $45,00 \mathrm{abc}$ & $34,00 \mathrm{a}$ \\
\hline Bima (biji) & $1,00 \mathrm{~b}$ & $48,60 \mathrm{abc}$ & $24,70 \mathrm{abc}$ \\
\hline Pikatan & $1,00 \mathrm{~b}$ & $36,80 \mathrm{bc}$ & $17,70 \mathrm{c}$ \\
\hline Tuk-Tuk & $1,00 \mathrm{~b}$ & $33,90 \mathrm{c}$ & $19,30 \mathrm{bc}$ \\
\hline Tajuk & $1,00 \mathrm{~b}$ & $40,20 \mathrm{bc}$ & $18,30 \mathrm{c}$ \\
\hline BM 8705 & $2,00 \mathrm{~b}$ & $51,40 \mathrm{abc}$ & $28,30 \mathrm{abc}$ \\
\hline Sanren & $2,00 \mathrm{~b}$ & $56,10 \mathrm{ab}$ & $33,00 \mathrm{ab}$ \\
\hline Manjung & $2,00 \mathrm{~b}$ & $60,30 \mathrm{a}$ & $31,30 \mathrm{abc}$ \\
\hline
\end{tabular}

Angka-angka yang diikuti huruf yang sama pada kolom yang sama menunjukkan tidak berbeda nyata pada uji BNJ taraf 5\%.

Sumber: Wati dan Sobir (2018) 


\section{- Kerapatan Tanaman}

Kerapatan tanaman berhubungan erat dengan jarak tanam dan populasi tanaman per satuan luas. Kerapatan tanaman juga erat kaitannya dengan persaingan antar tanaman dalam memanfaatkan unsur hara, air, cahaya, dan ruang. Sumarni, Sumiati, dan Suwandi (2005) telah melakukan pengujian terhadap tiga macam kerapatan tanaman, yaitu: $5 \times 5$ $\mathrm{cm} \quad\left(400\right.$ tanaman $\left./ \mathrm{m}^{2}\right), 5 \times 7,5 \mathrm{~cm}(266$ tanaman $\left./ \mathrm{m}^{2}\right)$, dan $5 \times 10 \quad \mathrm{~cm} \quad(200$ tanaman $/ \mathrm{m}^{2}$ ) pada daerah yang memiliki ketinggian $1.250 \mathrm{~m}$ dpl (dataran tinggi). Hasilnya, kerapatan tanaman paling tepat untuk memproduksi umbi benih bawang merah asal biji di dataran tinggi adalah 400 tanaman $/ \mathrm{m}^{2}$ dengan jumlah umbi berukuran kecil (2,5-5 g/umbi) paling banyak dan tidak menghasilkan umbi benih mini (1-2 g/umbi). Kerapatan tanaman 200 tanaman $/ \mathrm{m}^{2}$ lebih cocok digunakan untuk produksi umbi konsumsi asal biji dengan $50 \%$ umbi yang dihasilkan berukuran besar (>7,5 g/umbi). Di dataran rendah, Sumarni, et. al. (2012) menguji dua macam jarak tanam yaitu: 100 tanaman $/ \mathrm{m}^{2}$ dan 150 tanaman $/ \mathrm{m}^{2}$. Ternyata, hasil umbi kering asal biji tertinggi didapatkan pada kerapatan 100 tanaman $/ \mathrm{m}^{2}$. Dapat disimpulkan bahwa untuk mendapatkan produktivitas yang tinggi, penanaman di dataran tinggi sebaiknya lebih rapat dibandingkan di dataran rendah.

Sementara itu, tidak didapatkan interaksi antara kerapatan tanaman dan aplikasi zat pengatur tumbuh (ZPT) mepiquat klorida 50 AS terhadap hasil umbi bawang merah varietas Bima yang berasal dari biji (Sumarni, et. al., 2005). Juga tidak didapatkan interaksi kerapatan tanaman dengan varietas terhadap hasil umbi bawang merah asal biji (Sumarni, et. al., 2012). Di sisi lain, penelitian Sitepu, Ginting, dan Mariati (2013) yang menguji empat tingkat dosis pupuk Kalium dan tiga macam kerapatan tanaman (jarak tanam) di dataran rendah $(25 \mathrm{~m} \mathrm{dpl})$ menemukan bahwa adanya interaksi penggunaan pupuk Kalium dan jarak tanam terhadap bobot kering umbi bawang merah asal biji (Tabel 6). Bobot umbi kering terbaik didapatkan pada kombinasi perlakuan $20 \mathrm{~g} \mathrm{KCl} / \mathrm{m}^{2}$ (200 kg/ha) dan jarak tanam 10x10 cm. Selanjutnya, penelitian Sopha, Syakir, Setiawati, Suwandi, \& Sumarni (2017) di dataran rendah $(100 \mathrm{~m}$ dpl $)$ dan lahan LMK (suboptimal) juga mendapatkan adanya interaksi umur benih dan kerapatan tanaman terhadap bobot umbi kering eskip per tanaman dan bobot umbi kering eskip per petak, serta susut bobot umbi. Namun, tidak ada interaksi antara umur benih, kerapatan tanaman, dan dosis pupuk $\mathrm{N}$. Kombinasi umur benih (6 MSS=minggu setelah semai), kerapatan tanaman (150 tanaman $\left./ \mathrm{m}^{2}\right)$, dan dosis $\mathrm{N}(225 \mathrm{~kg} / \mathrm{ha})$ menghasilkan bobot umbi basah dan bobot kering eskip tertinggi, masing-masing sebesar 4,195 kg/2,4 $\mathrm{m}^{2}$ (setara 17,48 ton/ha) dan 2,80 kg/2,4 m² (setara 11,67 ton/ha).

Tabel 6. Bobot kering umbi per plot akibat pengaruh penggunaan pupuk Kalium dan jarak tanam.

\begin{tabular}{|c|c|c|c|c|}
\hline \multirow{2}{*}{$\begin{array}{c}\text { Pupuk Kalium } \\
(\mathrm{kg} / \mathrm{ha})\end{array}$} & \multicolumn{3}{|c|}{ Jarak Tanam $(\mathbf{c m})$} & \multirow{2}{*}{ Rata-rata } \\
\cline { 2 - 4 } & $\mathbf{1 0 x 1 0}$ & $\mathbf{1 0 x 1 5}$ & $\mathbf{1 0 x 2 0}$ & \\
\hline 0 & $0,19 \mathrm{a}$ & $0,25 \mathrm{ab}$ & $0,23 \mathrm{ab}$ & 0,22 \\
\hline 100 & $0,30 \mathrm{bc}$ & $0,27 \mathrm{abc}$ & $0,26 \mathrm{abc}$ & 0,28 \\
\hline 200 & $0,40 \mathrm{~d}$ & 0,31 bcd & $0,25 \mathrm{ab}$ & 0,32 \\
\hline 300 & $0,34 \mathrm{~cd}$ & $0,30 \mathrm{bc}$ & $0,26 \mathrm{abc}$ & 0,30 \\
\hline Rata-rata & $\mathbf{0 , 3 1}$ & $\mathbf{0 , 2 8}$ & $\mathbf{0 , 2 5}$ & \\
\hline
\end{tabular}

Angka-angka yang diikuti huruf yang sama menunjukkan tidak berbeda nyata pada uji Duncan taraf $5 \%$.

Sumber: Sitepu, et. al. (2013) 


\section{- Pemupukan}

Pupuk (organik dan anorganik) merupakan salah satu faktor penting yang berperan dalam meningkatkan produktivitas tanaman bawang merah asal biji. Namun, penelitian tentang pengaruh pemupukan pada tanaman bawang merah asal biji belum banyak dilakukan. Assad dan Warda (2010) telah melakukan penelitian penggunaan pupuk organik dan anorganik di Kabupaten Sidrap, Sulawesi Selatan. Ternyata, penggunaan pupuk organik atau anorganik atau organik dikombinasikan dengan anorganik mampu meningkatkan hasil bawang merah 17,63$79,49 \%$. Penggunaan pupuk organik yang dikombinasikan dengan pupuk anorganik memberikan pengaruh yang baik terhadap pertumbuhan dan hasil bawang merah asal biji. Bobot umbi kering tertinggi didapatkan pada perlakuan pupuk zeoorganik $5 \mathrm{t} / \mathrm{ha}+200 \mathrm{~kg}$ Urea $+150 \mathrm{~kg} \mathrm{SP}-$ 36 dan $200 \mathrm{~kg} \mathrm{KCl} / \mathrm{ha}$, yaitu 233,70 g umbi kering per 10 tanaman atau setara dengan 15,58 t/ha (Tabel 7).

Selanjutnya, penelitian umur benih, kerapatan tanaman, dan dosis pupuk $\mathrm{N}$ yang dilakukan Sopha et al. (2017) di dataran rendah mendapatkan bahwa kombinasi yang terbaik untuk menghasilkan bobot umbi basah dan bobot kering eskip tertinggi adalah pada perlakuan umur benih 6 mst, kerapatan tanaman 150 tanaman $/ \mathrm{m}^{2}$, dan dosis $225 \mathrm{~kg}$ $\mathrm{N} / \mathrm{ha}$, yaitu masing masing sebesar 4,195 $\mathrm{kg} / 2,4 \mathrm{~m}^{2}$ dan $2,80 \mathrm{~kg} / 2,4 \mathrm{~m}^{2}$.

Tabel 7. Pengaruh pemupukan terhadap berat umbi basah dan umbi kering bawang merah asal biji.

\begin{tabular}{|c|c|c|c|c|}
\hline \multirow{2}{*}{ Perlakuan } & \multicolumn{2}{|c|}{ Berat Umbi (g/10 tanaman) } & \multirow{2}{*}{$\begin{array}{l}\text { Hasil } \\
\text { (t/ha) }\end{array}$} & \multirow{2}{*}{$\begin{array}{l}\text { Peningkatan } \\
\text { Hasil }(\%)\end{array}$} \\
\hline & Basah & Kering & & \\
\hline Kontrol (Tanpa pemupukan) & $180 \mathrm{a}$ & $130,2 \mathrm{a}$ & 8,68 & - \\
\hline $\begin{array}{l}\text { Pupuk Zeo Organik } 5 \text { t/ha (tanpa pemberian } \\
\text { herbisida, insektisida dan fungisida) }\end{array}$ & $200 \mathrm{~b}$ & $171,8 \mathrm{bc}$ & 11,45 & 31,91 \\
\hline $\begin{array}{l}\text { Tanpa pupuk organik + jenis dan dosis pupuk } \\
\text { berdasarkan perlakuan petani (Urea } 200 \mathrm{~kg} / \mathrm{ha} \text {, SP- } \\
36150 \mathrm{~kg} / \mathrm{ha} \text { dan } \mathrm{KCl} 200 \mathrm{~kg} / \mathrm{ha} \text { ) }\end{array}$ & 230 & $153,2 \mathrm{ab}$ & 10,21 & 17,63 \\
\hline $\begin{array}{l}\text { Pupuk organik (bokashi) } 5 \text { t/ha+ Urea } 175 \mathrm{~kg} / \mathrm{ha}+ \\
\mathrm{SP}-36175 \mathrm{~kg} / \mathrm{ha}+\mathrm{KCl} 175 \mathrm{~kg} / \mathrm{ha}+\mathrm{ZA} 400 \mathrm{~kg} / \mathrm{ha}\end{array}$ & $210 \mathrm{~b}$ & $199,2 \mathrm{~cd}$ & 13,28 & 52,99 \\
\hline $\begin{array}{l}\text { Pupuk Zeo Organik 2,5 t/ha+ Urea } 175 \mathrm{~kg} / \mathrm{ha}+\mathrm{SP}- \\
36175 \mathrm{~kg} / \mathrm{ha}+\mathrm{KCl} 175 \mathrm{~kg} / \mathrm{ha}+\mathrm{ZA} 400 \mathrm{~kg} / \mathrm{ha}\end{array}$ & 250 & $182,8 \mathrm{bc}$ & 12,19 & 40,44 \\
\hline $\begin{array}{l}\text { Pupuk Zeo Organik 3,5 t/ha+ Urea } 175 \mathrm{~kg} / \mathrm{ha}+\mathrm{SP}- \\
36175 \mathrm{~kg} / \mathrm{ha}+\mathrm{KCl} 175 \mathrm{~kg} / \mathrm{ha}+\mathrm{ZA} 400 \mathrm{~kg} / \mathrm{ha}\end{array}$ & 240 & 182,9 bc & 12,19 & 40,44 \\
\hline $\begin{array}{l}\text { Pupuk Zeo Organik } 5 \text { t/ha+Urea } 175 \mathrm{~kg} / \mathrm{ha}+\mathrm{SP}-36 \\
175 \mathrm{~kg} / \mathrm{ha}+\mathrm{KCl} 175 \mathrm{~kg} / \mathrm{ha}+\mathrm{ZA} 400 \mathrm{~kg} / \mathrm{ha}\end{array}$ & 250 & 219,5 & 14,63 & 68,55 \\
\hline $\begin{array}{l}\text { Pupuk Zeo Organik } 2,5 \mathrm{t} / \mathrm{ha}+\text { jenis dan dosis pupuk } \\
\text { berdasarkan perlakuan petani (Urea } 200 \mathrm{~kg} / \mathrm{ha} \text {, SP- } \\
36150 \mathrm{~kg} / \mathrm{ha} \text { dan } \mathrm{KCl} 200 \mathrm{~kg} / \mathrm{ha} \text { ) }\end{array}$ & 250 & 214,6 & 14,31 & 64,86 \\
\hline $\begin{array}{l}\text { Pupuk Zeo Organik 3,5 t/ha + jenis dan dosis pupuk } \\
\text { berdasarkan perlakuan petani (Urea } 200 \mathrm{~kg} / \mathrm{ha} \text {, SP- } \\
36150 \mathrm{~kg} / \mathrm{ha} \text { dan } \mathrm{KCl} 200 \mathrm{~kg} / \mathrm{ha} \text { ) }\end{array}$ & 250 & 225,1 & 15,01 & 72,93 \\
\hline $\begin{array}{l}\text { Pupuk Zeo Organik } 5 \mathrm{t} / \mathrm{ha}+\text { jenis dan dosis pupuk } \\
\text { berdasarkan perlakuan petani(Urea } 200 \mathrm{~kg} / \mathrm{ha}, \mathrm{SP}- \\
36150 \mathrm{~kg} / \mathrm{ha} \text { dan } \mathrm{KCl} 200 \mathrm{~kg} / \mathrm{ha})\end{array}$ & 260 & 233,7 & 15,58 & 79,49 \\
\hline
\end{tabular}

Angka-angka yang diikuti huruf yang sama pada kolom yang sama menunjukkan tidak berbeda nyata pada uji Duncan taraf $5 \%$.

Sumber: Assad dan Warda (2010)

\section{- Produksi Lipat Ganda (Proliga) Bawang Merah}

Saat ini, Kementerian sedang mengembangkan inovasi teknologi produksi lipat ganda (proliga) bawang merah. Penerapan teknologi ini diharapkan mampu meningkatkan produktivtas bawang merah menjadi $30-40$ t/ha 
(Kusumasari et al. 2019; Suwandi, Sopha, and Hermanto 2016). Benih bawang merah yang berasal dari biji terlebih dahulu disemaikan di media pesemaian selama 5-6 minggu dengan kebutuhan benih berkisar 2,38-7,14 kg/ha atau rata-rata $5 \mathrm{~kg} / \mathrm{ha}$, tergantung jarak tanam dan jumlah benih per lubang tanam. Benih ditanam sebanyak 2-3 benih per lubang tanam, dengan jarak tanam 10x10 cm. Secara umum, pemupukan diberikan berupa pupuk dasar pada fase akhir penyiapan lahan sebanyak 4-5 t/ha pupuk kandang ditambah 400-500 $\mathrm{kg} / \mathrm{ha}$ NPK Phonska. Sedangkan kapur dolomit sebanyak 1-2 t/ha diberikan pada saat pengolahan tanah. Pupuk susulan pertama diberikan umur 3-4 mst sebanyak $400 \mathrm{~kg} / \mathrm{ha}$ NPK Mutiara ditambah (150200) $\mathrm{kg} / \mathrm{ha}$ ZA. Pupuk susulan kedua diberikan umur 6-7 mst, sebanyak 400 $\mathrm{kg} / \mathrm{ha}$ NPK (15-9-20) Hydrokompleks (Grower) (Suwandi et al. 2016). Di Jawa Tengah, Kusumasari et al. (2019) merekomendasikan pemberian pupuk dasar sebanyak $20 \mathrm{t} / \mathrm{ha}$ pupuk kandang ditambah $533 \mathrm{~kg} / \mathrm{ha}$ NPK (15:15:15), $111 \mathrm{~kg} / \mathrm{ha}$ SP36, $66 \mathrm{~kg} / \mathrm{ha} \mathrm{KCl}$, dan 2 t/ha dolomit. Pupuk susulan diberikan sebanyak 400 $\mathrm{kg} / \mathrm{ha}$ NPK Mutiara umur 10, 20, dan 30 hst, masing-masing $1 / 2,1 / 3$, dan $1 / 3$ bagian. Pupuk ZA sebanyak $200 \mathrm{~kg} / \mathrm{ha}$ diberikan umur 15 dan 30 hst, masing-masing $1 / 2$ bagian. Pupuk $\mathrm{KNO}_{2}$ putih diberikan sebanyak $50 \mathrm{~kg} / \mathrm{ha}$ pada umur $10 \mathrm{hst}$, sedangkan pupuk $\mathrm{KNO}_{2}$ merah diberikan sebanyak $150 \mathrm{~kg} / \mathrm{ha}$, masing-masing 1/2 bagian pada umur 20 dan 30 hst. Dapat disimpulkan, pemberian pupuk untuk budidaya bawang merah dengan teknologi proliga berbeda disetiap daerah. Dianjurkan pemberian pupuk berdasarkan rekomendasi setempat (spesifik lokasi).

\section{KESIMPULAN DAN SARAN}

1. Teknologi budidaya bawang merah asal biji dapat menghemat biaya pembelian benih sampai $66,7 \%$ dan meningkatkan hasil menjadi 30-40 t/ha.
2. Untuk mendapatkan produktivitas bawang merah asal biji yang tinggi, kelas kesesuaian lahan dapat dipedomani karena berkaitan dengan tambahan masukan (input) usahatani, meliputi: sangat sesuai (S1), cukup sesuai (S2), sesuai marginal (S3), dan tidak sesuai $(\mathrm{N})$.

3. Proses perbanyakan benih bawang merah dianjurkan pada daerah yang memiliki ketinggian 1.000-1.500 m dpl. Namun, di dataran rendah juga berpeluang dengan menambahkan beberapa perlakuan, seperti pemberian BAP (benzilaminopurin) dan boron.

4. Terdapat banyak varietas yang dapat digunakan untuk budidaya bawang merah asal biji, antara lain; Bima, Pikatan, Tuk Tuk, Tajuk, BM 8705, Sanren, Manjung, Trisula, dan Pancasona. Namun, varietas-varietas ini perlu diuji daya adaptasinya pada lokasi spesifik (dataran rendah maupun dataran tinggi).

5. Penanaman di dataran tinggi sebaiknya lebih rapat dibandingkan di dataran rendah.

6. Pupuk diberikan dalam bentuk pupuk organik dan anorganik. Namun, diperlukan penelitian tentang kebutuhan pupuk untuk budidaya bawang merah spesifik lokasi.

7. Informasi tentang komponen teknologi budidaya bawang merah asal biji masih sedikit sehingga diperlukan penelitian-penelitian untuk mendapatkan komponen teknologi bawang merah spesifik lokasi.

\section{UCAPAN TERIMAKASIH}

Kepada Prof. Dr. Ir. Irfan Suliansyah, MS sebagai promotor, dan Prof. Dr. Ir. Aswaldi Anwar, M.Si, dan Dr. Ir. Syafrimen Yasin, M.Sc masing-masing sebagai co promotor pada Program Studi S3 Ilmu Pertanian Fakutas Pertanian Universitas Andalas Padang yang telah 
membimbing penulis hingga terbitnya artikel ini, diucapkan terima kasih banyak.

\section{DAFTAR PUSTAKA}

Assad, Muh, and Warda. 2010. "Kajian Penggunaan Pupuk Organik Pada Tanaman Bawang Merah Asal Biji Di Kabupaten Sidrap, Sulawesi Selatan.” Jurnal Pengkajian Dan Pengembangan Teknologi Pertanian 13(1):20-28.

BPS. 2018. "Statistik Indonesia 2018.” 761. Kusumasari, Aryana Citra, Imam Firmansyah, Ridha Nurlaily, and Fitri Lestari. 2019. "Budidaya Bawang Merah Dengan Teknologi Proliga (Produksi Lipat Ganda)." 11.

Nurjanani, and Fadjry Djufry. 2018. "Uji

Potensi Beberapa Varietas Bawang Merah Untuk Menghasilkan Biji Botani Di Dataran Tinggi Sulawesi Selatan ( Test Potential for Some Variety to Produce True Shallot Seed in Highland South Sulawesi )." $J$. Hort. 28(2):201-8.

Pangestuti, Retno; Sulistyaningsing, Endang. 2011. "Potensi Penggunaan True Seed Shallot (TSS) Sebagai Sumber Benih." Prosiding Semiloka Nasional (September):258-66.

Ritung, Sofyan, Kusumo Nugroho, Anny Mulyani, and Erna Suryani. 2011. Petunjuk Teknis Evaluasi Lahan Untuk Komoditas Pertanian. Bogor: Balai Besar Penelitian Pengembangan Sumberdaya Lahan Pertanian. Balitbangtan.

Rosliani, R., ER Palupi, and Y. Hilman. 2013. "Pengaruh Benzilaminopurin Dan Boron Terhadap Pembungaan , Viabilitas Serbuk Sari, Produksi, Dan Mutu Benih Bawang Merah Di Dataran Rendah ( The Effect of Benzylaminopurine and Boron Application On Flowering, Pollen Viability , Production , and Quality." J. Hort. 23(4):339-49.

Saidah, Muchtar, Syafruddin, and
Pangestuti Retno. 2019. "Pertumbuhan Dan Hasil Panen Dua Varietas Tanaman Bawang Merah Asal Biji Di Kabupaten Sigi , Sulawesi Tengah Growth and Yield of Two Shallot Varieties from True Shallot Seed in Sigi District, Central Sulawesi." Pp. 213-16 in Pros. Sem Nas Masy Biodiv Indon. Vol. 5.

Sembiring, Asma, Rini Rosliani, Sortha Simatupang, Paulina Evy Prahardini, and Sri Rustini. 2018. "Kelayakan Finansial Produksi True Shallot Seed Di Indonesia ( Studi Kasus : Sumatera Utara , Jawa Timur, Dan Jawa Tengah ) [ Financial Feasibility of True Shallot Seed Production in Indonesia ( Case Study: North Sumatera , East Java, and Central Java )." J. Hort. 28(2):289-98.

Sitepu, Benhard H., Sabar Ginting, and Mariati. 2013. "Respon Pertumbuhan Dan Produksi Bawang Merah (Allium Ascalonicum L. Var. Tuk-Tuk) Asal Biji Terhadap Pemberian Pupuk Kalium Dan Jarak Tanam." Jurnal Online Agroekoteknologi 1(3):711-24.

Sopha, Gina Aliya, Muhammad Syakir, Wiwin Setiawati, Suwandi, and Nani Sumarni. 2017. "Teknik Penanaman Benih Bawang Merah Asal True Shallot Seed Di Lahan Suboptimal ( Planting Method of Seedling of Shallot from True Shallot Seed in Suboptimal Land )." J. Hort. 27(1):35-44.

Sumarni, N., E. Sumiati, and Suwandi. 2005. "Pengaruh Kerapatan Tanaman Dan Aplikasi Zat Pengatur Tumbuh Terha- Dap Produksi Umbi Bibit Bawang Merah Asal Biji Kultivar Bima." J. Hort. 15(3):208-14.

Sumarni, Sopha GA N, and R. Gaswanto. 2012. "Respons Tanaman Bawang Merah Asal Biji True Shallot Seeds Terhadap Kerapatan Tanaman Pada Musim Hujan." J. Hort. 22(1):23-28. 
Suwandi, Gyna A. Sopha, and Catur Hermanto. 2016. Petunjuk Teknis (Juknis) Proliga Bawang Merah 40 t/Ha Asal TSS ( = True Shallot Seed ). Lembang Jawa Barat.

Wati, Tika Anisa Padar, and Sobir. 2018. "Keragaan Tujuh Varietas Bawang
Merah ( Allium Cepa L . Aggregatum Group ) TSS ( True Shallot Seed ) Performance of Seven Varieties of Shallot ( Allium Cepa L . Aggregatum Group ) TSS ( True Shallot Seed )." J. Hort. 2(3):16-24. 